\title{
Ecotourism-Based Learning Models in Efforts to Implement Effective Learning: A conceptual research
}

\author{
${ }^{1 *}$ Moch. Agus Krisno Budiyanto, ${ }^{1}$ Samsun Hadi, ${ }^{2}$ Tien Aminah, ${ }^{1}$ H. Husamah \\ ${ }^{1}$ Biology Education Study Program, FTTE, Universitas Muhammadiyah Malang; Jl. \\ Tlogomas 246 Malang Tel. 464318 psw 120, Indonesia \\ ${ }^{2}$ ITSK RS dr. Soepraoen Malang; Jl. S. Supriadi No.22, Sukun, Kec. Sukun, Malang City, \\ East Java 65147 \\ *Corresponding Author e-mail: aguskrisno@umm.ac.id
}

Received: November 2020; Revised: December 2020; Published: December 2020

\begin{abstract}
Various previous studies have shown that ecotourism has great potential and benefits when associated with education and especially in learning. This review study aimed to explore an ecotourism-based learning model at the high school level in Malang, East Java. The focused in the review were (1) competencies and indicators of learning outcomes of all subjects in all subjects that could apply ecotourism-based learning 2) the potential for regional ecotourism (especially school environments in East Java) which could be used for ecotourism-based learning based on competencies and outcome indicators learning, and 3) drafted recommendations for learning models based on ecotourism. Based on the results of a review of various references, it can be stated that four things need to be considered in the application of an ecotourism-based learning model, namely the conceptual framework, planning, implementation, evaluation, and furthering the ecotourism-based learning model. Furthermore, It was necessary to develop an ecotourism-based Learning Model that follows an appropriate development model, so that an implementable model is produced.
\end{abstract}

Keywords: Ecotourism; Learning Models; Effective Learning

How to Cite: Budiyanto, M., A., K., Hadi, S., Aminah, T., \& Husamah, H. (2020). Ecotourism-Based Learning Models in Efforts to Implement Effective Learning: A conceptual research. Prisma Sains : Jurnal Pengkajian Ilmu dan Pembelajaran Matematika dan IPA IKIP Mataram, 8(2), 69-80. doi:https://doi.org/10.33394/jps.v8i2.3234

https://doi.org/10.33394/j-ps.v8i2.3234

Copyright $\odot$ 2020, Budiyanto et al This is an open-access article under the CC-BY License. (c) (i)

\section{INTRODUCTION}

SMA level requires the implementation of effective learning (Agustin et al., 2019; Alkhararbeh, 2019; Cohen et al., 2019; OECD, 2009; Prameswari \& Budiyanto, 2017; Zwane \& Malale, 2018). Effective learning is a learning process to build meaning/understanding of information and/or experiences (Bradshaw, 2004; Eysenck \& Eysenck, 2018; Fazey et al., 2005; Hewitt, 2008). In implementing effective learning, learning resources are needed that are not only in school but also outside of school (Claiborne et al., 2017; Watkins et al., 2005). One of the potential learning resources that can be used to support effective learning is the potential for ecotourism, which has recently become a trend.

Ecotourism is a form of responsible travel to natural areas to conserve the environment and preserve the lives and welfare of residents (Boo, 2008; TIES, 2016). Ecotourism emphasizes the balance between enjoying the natural beauty and efforts to conserve the environment (nature and culture) and increasing community participation in its management (Adeniran \& Akinlabi, 2014; Butarbutar \& Soemarno, 2012; Gabdrakhmanov et al., 2016).

In this connection, Malang Raya has a lot of potential for ecotourism which can be used as a learning resource (Boedirachminarni \& Suliswanto, 2017; Husamah \& Hudha, 2018; Wulandari et al., 2020). Research result Budiyanto (2006) the typology of developing 
ecotourism potential in East Java shows that in general all districts/cities strive to develop their eco-tourism potential. Research result Budiyanto (2007) the typology of utilizing the potential of ecotourism as a learning resource in East Java Senior High School shows that there is a trend for schools to take advantage of the potential for ecotourism in learning, even though it is not optimal because it is still incidental and is associated with field trip events. The ability of teachers in ecotourism-based learning consists of (1) planning for ecotourismbased learning, (2) implementing ecotourism-based learning, (3) evaluating ecotourism-based learning, and (4) follow-up learning based on ecotourism is still not growing optimally.

Research and development activities that are oriented to develop an ecotourism-based learning model by exploiting the potential of ecotourism in the school environment are needed. This ecotourism-based learning model is expected to be used as an effective learning strategy so that it will increase the dynamics (performance) of learning which has implications for improving learning outcomes. On the other hand, the application of an ecotourism-based learning model will optimize the utilization of the potential of ecotourism which has recently been developed by local governments. Based on this description, an article review is required as a first step. This review aims to explore an ecotourism-based learning model at the high school level in Malang, East Java.

\section{METHOD}

The perspective or method used in the review was a literature study, referring to Fink (2014) and (Caulley, 2007). Literature studies was carried out by surveying various primary references that have relevance to the problem, field of study, theory, and the subject being reviewed. Literature studies were designed to provide an overview of the sources that have been explored when researching/studying a particular topic and to show the reader its suitability with a larger topic aspect.

Meanwhile, this review also used content analysis. Content analysis was a systematic technique for analyzing the meaning of messages and how to express the messages. The steps taken in the content analysis follow an interactive model (Miles et al., 2019). This model contained four interrelated components, namely (1) data collection, (2) data simplification or reduction, (3) data presentation, (4) drawing and testing, or verification of conclusions. Analytical constructs can come from (1) existing theory or practice; (2) experience or knowledge of experts; and (3) previous research (White \& Marsh, 2006).

The focus of this study were 1) competency and indicators of learning outcomes for all subjects in the 2004 curriculum that can implement ecotourism-based learning 2) the potential for regional ecotourism (school environment) which can be used for ecotourismbased learning based on competencies and learning outcome indicators, and 3) drafting a learning model based on ecotourism.

In this connection, the author has explored various primary literature. Search was done through online media with the help of the Google search engine. The literature, namely various scientific articles published in scientific journals and proceedings (both national and international), various research reports, papers, books, newspapers, government regulations or policies (central and local), online news, and various other literary sources. To ensure the validity and reputation of the source, the author only used sources that have a URL so that if one day was checked by the reader, it will remain traceable. The keywords used to search Indonesian literature on Google are "ekotourisme", "ekowisata", "ekowisata Kota Batu", "Ekowisata Jawa Timur", "pembelajaran berbasis ekotourisme", "perencaaan pembelajaran + ekotourisme", "pelaksanaan pembelajaran + ekotourisme", "evaluasi pembelajaran + ekotourisme", dan "kebijakan + pendidikan + ekotourisme". The same keywords, but in the English version were used to search for international references. 


\section{RESULTS AND DISCUSSION}

\section{Ecotourism-Based Learning Concept Framework}

The combination of educational and recreational methodologies had the potential to be implemented in conservation areas, national parks, nature reserves, and large forests (Maryani, 2020; Rusita et al., 2016). For this reason, the choice of learning process approach and program packaging could be done using the Experiential Learning (EL) method. Choosing this method was considered relevant to the subject of education and regional conditions.

The EL learning method was intended so that students would be able to evaluate actions, then determine the goals be achieved by predicting what will happen (Julismin, 2009; Maulana, 2015). Students would be faced with conditions that can later be implemented in everyday life, and also made understanding of a problem higher so that its implementation was also easier (Girvan et al., 2016; Gleason et al., 2011; Schwartz, 2012). Every community (visitors) would see and experience the potential of nature, forests, rivers, flora, and fauna that they had only heard of from various media. Management of outdoor training (outing, gathering, and outbound) by making conservation areas, national parks, nature reserves, botanical parks, seas, and beaches or other places as a means of self-formation (personal and team) could be combined with materials and syllabus appropriate (management, conservation, and recreation).

The readiness of training or learning programs in nature focused more on developing the following, namely (1) increasing self-confidence (Mudzakir \& Mubarok, 2020; Widyaningtyas \& Farid, 2015); (2) Group cooperation: Interdependence, cooperation, the importance of communication and building a compact team were the goals of this training (Team Building and Team Work) (Faraitody \& Ramadhan, 2015; Setiyanti, 2012); and (3) This training program sharpened the spirit of leadership in the participants (Farida \& Anjani, 2019; Fauziyah, 2018). Participants needed to face existing problems with quality decision making. The participants' self-confidence, ability to lead groups, independence, and the ability to nurture would be explored and studied as provisions for their leadership in everyday life.

Ecotourism Based Learning could not be separated from the spirit of effective learning. Effective learning was a learning process to build meaning/understanding of information and/or experiences (Agustin et al., 2019; Bradshaw, 2004; Hewitt, 2008; OECD, 2009; Prameswari \& Budiyanto, 2017). The process of constructing meaning could be carried out alone by students or with others in various environmental conditions. The process was filtered by students' perceptions, thoughts (initial knowledge), and feelings (Coe et al., 2014; Schunk, 2012). In this paradigm, learning was not a process of absorbing knowledge that had been formed by the teacher. Effective learning could be done through education within the school environment and educational activities carried out outside the school environment in the form of provided various learning experiences for all students. This means, curriculum diversification was not limited to the diversification of material but also occured in the diversification of learning experiences, diversification of learning placed and timed, diversification of learning tools, diversification of class organization form, and diversification of assessment methods.

This view has an impact on the implementation of learning. If so far learning had only been characterized by a one-way activity of poured information from teacher to student and was only carried out and taking place in schools, effective learning was indicated by active student involvement in building ideas/knowledge by each individual and could generally be hold in several locations such as in class, in the school environment, in the library, in the laboratory, at the market, at the shop, on the beach, in a recreation area, in a zoo, or other places. Therefore, an effective learning strategy that could be implemented in connection with Ecotourism-Based Learning is problem-based learning (Silva et al., 2018; Yew \& Goh, 2016), authentic instruction (Cydis, 2015; Mims, 2003), inquiry-based learning (Andrini, 
2016; Pedaste et al., 2015; Singh \& Kaushik, 2020), project-based learning (Husamah \& Rahardjanto, 2018; Rahardjanto et al., 2019), work-based learning (Atkinson, 2016; Smith \& Betts, 2000; Stevens, 2014), and cooperative learning (Gull \& Shehzad, 2015; Hsiung, 2012). In lined with the view area (2005), it could be stated that effective learning required learning resources that were not only in school but also outside of school. One of the potential learning resources that could be used to support effective learning was the potential for ecotourism, which has recently become a trend of developing regional potential in the autonomy era.

\section{Planning a Learning Model Based on Ecotourism}

Several things needed to be considered in planning an Ecotourism-Based Learning Model. Some of these things could be described one by one as follows.

\section{Determination of Time to Use Ecotourism Potential as a Learning Source}

Basic determination time to utilized the potential of ecotourism as a learning resource was an effective week. Determining the timing of the implementation of ecotourism-based learning must also payed attention to the school's academic and non-academic activities. As far as possible, implementing ecotourism-based learning could involved as many students and teachers as possible from various levels of classes, departments, and subject teachers. This was intended so that ecotourism-based learning was efficient and effective. According to Baroroh (2019), the teaching and learning process used ecotourism patterns often required a lot of time and was often forced to take other lessons, so that plant should pay attention to the time aspect.

\section{Formulation of Learning Objectives (Basic Competencies) Subjects}

The formulation of basic competencies that were expected to be achieved in ecotourism-based learning was determined based on the time agreed by most teachers and students, semester programs, and syllabus for each subject. According to Baroroh (2019) Learning methods that were following by the material and characteristics of students would help achieve learning objectives so that the ability of teachers to formulate quality learning objective and resource would greatly help to master students' competencies.

\section{Identification of Learning Resources and Potential Needed}

Identification of the required learning resources could only be determined after the basic competencies of subjects to be achieved in ecotourism locations are decided based on students and subject teachers who participate in the availability of time (length of stay) at the ecotourism location. After determining the need for learning resources at the ecotourism location, then the ecotourism location was determined which is planned to be used as an ecotourism-based learning place.

The next stage was to identified the potential for ecotourism that can be used as a learning resource based on indicators TIES (2016). Services to ecotourism customers could be done by developing the potential for ecotourism with the following indicators: 1) The physical condition of the area (area, altitude, air, etc.), 2) The area's biotic potential(flora and fauna), 3) Potential tourism which includes: natural tourism with activities in the form of hiking, camping, horse riding, cycling and the like; relaxing tours while exercising: tennis, swimming (hot water), natural lines and others; convention tours: tourism activities while conducting seminars, meetings, conferences and so on; and cultural tourism: activities in the form of traditional art performances, 4) Infrastructure facilities such as the construction of an information center, work huts, sports facilities, camping ground, children's playgrounds, hot spring baths, shelters, lodging facilities, places of worship, and meeting rooms, 5) Accessibility (ease of reaching tourist attractions). Based on the existing potential, a basic competency was redefined which was expected to be achieved in the ecotourism location effectively. 
Learning resources allowed and facilitated the learning process. The natural wealth that existed in the territory of Indonesia could be used as an alternative source of learning to teach biology materials by doing Ecotourism activities (Suryaningsih, 2018).

\section{Preparation of Syllabus, Lesson Plans, and Student Worksheets}

The formulation of plans to utilized the potential of ecotourism as a source of effective learning could used the following types: 1) Typology of plan initiators: a) Student-Teacher Inquisitor (STI) and b) Teacher-Student Inquisitor (TSI), 2) Typology of planning policymaking process: a) Top-Down, b) Bottom-Up, and c) Top-Down and Bottom-Up relations, and 3) Typology of implementing planning: a) Collaborative / Resource sharing, Semicollaborative where the promoter of the plan was a biology teacher and the supporter of the plan was another teacher (Budiyanto, 2006, 2007, 2010).

Some of the steps for prepared a plan were as follows: 1) The began of learning forms a working group for subject teachers and students, 2) Provided suitable alternative tourist areas, 3) Notified parents of student guardians that there will be nature-based learning (ecotourism), 4) Students and/or teachers made location observations., 5) Made a statement of ability to take part in nature tourism activities, and 6) Arranged rules with students and mentor teachers whose results were known by the school and the parents of students' guardians.

\section{Implementation of Ecotourism Based Learning Model}

The implementation of the utilization of the potential of ecotourism as a source of effective learning could be done in two types, namely a) Collaborative/Resource Sharing and b) Semicollaborative. In the Collaborative type, all teachers were directly involved in ecotourism-based learning to achieve the basic competencies of their respective subjects, while in the Semicollaborative type, the implementation coordinator was the biology teacher and implementation supporters are other teachers.

Some of the steps to carry out the utilization of the potential of ecotourism as a source of effective learning were as follows: (1) Each class was divided into several groups; (2) Each group works on the LKS that had been provided; (3) Each group was guided by one / two mentors; (4) Before working on the worksheets, the time was determined; (5) All group members must actively participate in the discussion in completing the LKS; (6) If there were difficulties, ask the supervisor for directions; and (7) at the end of the ecotourism lesson each group reports on their work.

On the other hand, several steps in implementing the utilization of the potential of eco ism as a source of effective learning that needed to be considered were as follows: (1)Arranged a schedule of events before being in a natural tourism area combined with the results of observations; (2) Prepared a schedule for the students to do when studying in a natural tourism area, in the form of questions/questions; and (3) Informed the tools and materials that would be used for learning in natural tourism areas.

The used of ecotourism as a learning resource can provide fun learning, contextually learning could develop learning methodologies, and it was hoped that a better understanding for students of the objects and concepts being studied (Brown, 2010; Lotulung et al., 2018; Podschuweit \& Bernholt, 2018). This activity was carried out related to materials, midterm activities, and effective days that do not interfere with holidays.

\section{Assessment of Ecotourism Based Learning Models}

Assessment The results of the implementation of the utilization of the potential of ecotourism as a source of effective learning can used several approaches, namely Learning process evaluation, practical evaluation, and competence evaluation. Some of the steps in evaluating include the following: (1) The teacher made items that were used for scoring which will later be used as grades; (2) Asked one group to be an observer while the other group was making a presentation; (3) Asked each group to make a scientific report; (4) Presented the results of scientific reports in front of other groups; and (5) The teacher 
evaluated the results of the report and group discussion after the presentation (Aprilia, 2009; Asrul et al., 2014; Qodir, 2017; Ratnawulan \& Rusdiana, 2014).

Some things that needed to be considered in evaluating were as followed: (1)Assessed the suitability of learning objectives with objects observed at the location of ecotourism; (2) Payed attention to the achievement of student learning outcomes in ecotourism-based learning in the past; and (3) Payed attention to cost efficiency and timing of ecotourism implementation. Assessment could also be carried out after the activity, namely in the form of a report on the results of the activity that must be presented or in the form of a poster/wall magazine. Evaluation of the utilization of the potential of ecotourism as a source of effective learning can also be done in two ways, namely individual assessments and group assessments.

Some of the assessment strategies that can be used in ecotourism-based learning were as follows.

\section{Project Appraisal}

The term project in this scoring system was a task that students must completed within a certain time. This task was in the form of an investigation starting from collecting, organizing, evaluating, and presenting data. Since project implementation was based on primary or secondary data, evaluation of results, and collaboration with other parties, the project was an important means of assessing general capability in all areas. The project would also provided information about students' understanding and knowledge of specific learning, students' ability to applied knowledge, and students' ability to communicated information. (Asrul et al., 2014; Saepuddin, 2016).

In a curriculum that was oriented towards competency standards, learning outcomes could be assessed when students were in the process of a project, for example when planning and organizing investigations, working in teams, and when students direct themselves. Besides, there were learning outcomes that were more appropriate when assessed through the product of a project, for example when identifying and gathering information, analyzing and interpreting data, and when communicating project results. (Chaeroni, 2018; Poerwanti, 2015; Sunani, 2010).

In class, the teacher might emphasized project appraisal on the process and used it as a means of developing and monitoring student skills in planning, investigating, and analyzing projects. In this context, students could be provided experience and knowledge on a topic, formulated questions, and investigated the topic through reading, tours, and interviewed. Furthermore, their activities can be used to assess their ability to work independently or in groups. Also, the teacher could used the product of a project to assessed students' ability to communicated findings in the right form and in term of presenting result through visual displays and written reports.(Afandi et al., 2013; Arifin, 2011; Idris, 2007; Wijayanti, 2014; Yudha et al., 2014).

Before project appraisal activities were carried out, the teacher first needed to plan an assessment. In planning activities, it was necessary to consider management capability. If students were given a lot of freedom, they would have difficulty choosing the right topic. They might choose topics that were too broad so that little information can be found. They might also be inaccurate for estimating data collection and report writing times. Teachers must consider aspects of the relevance of knowledge, skills, and understanding to learning so that the project can be used as a source of evidence and consider how much guidance or support had been given to students (Asrul et al., 2014; Poerwanti, 2015).

\section{Assessment of Student Work Results}

Research student work was an assessment of student mastery of a skill in making a work result and the quality of student work. In assessing student work, there were two concepts of assessment, namely student assessment of job selection and how to use work 
tools and procedures. Apart from that, it was also an assessment of the technical quality and work (Ermawati \& Taufiq, 2017; Winaryati, 2018; Yudha et al., 2014).

Assessment of work results was aimed to (1) Assessed students' mastery of the skills needed before learning the next skill; (2) Assessed the level of competence that had been mastered at the end of each level/class in a vocational school; and (3) Assessed the skills of students who would enter vocational education institutions. In assessed student work, it was necessary to pay attention to aspects of the relevance of the work which included the competencies to be measured. Strategies that could be taken to ensure the relevance and scope of work results were to determine the competencies that would be measured every time you assign assignments to students, compiled each competency that will be measured at each stage of work results (planning, production, appraisal), and the number and objectivity of work results. (Asrul et al., 2014; Maharani \& Aima, 2014; Directorate of Junior High School Development Team, 2017).

Operationally, there were several methods that teachers can use to assess and record student work, among others, (a) Anecdotal notes, notes that the teacher made during observations of students during teaching and learning activities; (b) Analytic Ratings, assessments (judgments) made based on several aspects of student work; (c) Holistic rating, which is an assessment of the overall student work, and (d) a checklist, where the teacher usually writes down several skills that would be measured in each given task and then assess whether during the completion of the task the student had demonstrated the skill in question. So, the checklist only assessed the skills students could be perform, not their quality.

\section{The follow-up to the Implementation of Ecotourism-Based Learning Models}

The follow-up results of the evaluation of the implementation of the potential utilization of ecotourism as a learning resource for effective learning could use the pattern: a) Top-down strategy, where the type of follow-up was determined by the teacher, for example making poetry, worksheets, presentations, articles, wall magazine materials, and so on, b) Bottom-up strategy where the type of follow-up was up to students, for example making posters, leaflets, demos, and others, and c) Top-Down and bottom-up strategy, where the type of follow-up was offered by the teacher and agreed by the students.

some examples of follow-up results of the evaluation were as follows: (1) The teacher provided input in the form of criticism and suggestions which could build students to be more serious in observing and making scientific reports; (2) The teacher taken part of the results of scientific reports to make daily questions/block tests; (3) Written papers; (4) Made wall magazines; (5) Made a critical analysis; (6) Made a poetry; (7) Exhibitioned of activity results; (8) Seminar; (9) Portfolio; (10) Determined regular events or not; (11) Determined the location that must be visited in each lesson; (12) Changed the location and or object of ecotourism; and (13) Development of learning methods that was not bore students in contextual learning(Asrul et al., 2014; Mukhtar, 2015; Mulyadin, 2017).

\section{CONCLUSION}

Based on the results of the review, it can be stated that four things need to be considered in the application of an ecotourism-based learning model, namely the conceptual framework, planning, implementing, evaluating, and following up the ecotourism-based learning model.

\section{RECOMMENDATION}

Furthermore, It is necessary to develop an ecotourism-based Learning Model that follows an appropriate development model, so that an implementable model is produced.

\section{ACNOWLEDGEMENT}

The author would like to thank the DP2M Director of the Directorate General of Higher Education, Depdikbud for funding the research that was initiated in this review. Thank you 
also to the Leadership of the Universitas Muhammadiyah Malang and the Director of the DPPM UniversitasMuhammadiyah Malang, for their valuable assistance and information in this review.

\section{REFERENCES}

Adeniran, A. J., \& Akinlabi, F. J. (2014). Ecotourism landscapes: An editorial. American Journal of Tourism Management, 3(1A), 1-4. https://doi.org/10.5923/s.tourism.201401

Afandi, M., Chamalah, E., \& Wardani, O. P. (2013). Model dan metode pembelajaran di sekolah (G. Gunarto (Ed.)). UNISSULA Press. https://doi.org/10.1007/s00423-0060143-4

Agustin, H., Noviyenty, L., \& Utami, H. S. (2019). An analysis of classroom activities pursuant to effective techniques teaching English in integrated vocational schools. ENGLISH FRANCA: Academic Journal of English Language and Education, 3(2), 149-180. https://doi.org/10.29240/ef.v3i02.1112

Alkhararbeh, M. N. A. (2019). Problems of proper planning in effective teaching of high school students in salt schools. International Journal of Business and Management, 14(6), 53-63. https://doi.org/10.5539/ijbm.v14n6p53

Andrini, V. S. (2016). The Effectiveness of Inquiry Learning Method to Enhance Students ' Learning Outcome: A Theoritical and Empirical Review. Journal of Education and Practice, 7(3), 38-42.

Aprilia, B. (2009). Penerapan model pembelajaran diskusi kelompok menggunakan media question card untuk meningkatkan prestasi belajar sejarah pada siswa kelas XI Program Ilmu Sosial SMA Negeri 2 Wonogiri tahun ajaran 2008/2009 [UNNES]. http://lib.unnes.ac.id/73/

Arifin, A. (2011). Pengelolaan penilaian portofolio mata pelajaran Pendidikan Agama Islam di SD Negeri 6 Boja Kabupaten Kendal.

Asrul, A., Ananda, R., \& Rosinta, R. (2014). Evaluasi Pembajalaran. Citapustaka Media.

Atkinson, G. (2016). Work-based learning and work-integrated learning: fostering engagement with employers Work-based learning and work-integrated learning: fostering engagement with employers. In National Centre for Vocational Education Research. https://doi.org/10.1016/j.lmot.2010.04.007

Baroroh, K. (2019). Pembelajaran berbasis masalah ekowisata pada mata pelajaran ekonomi SMA. Jurnal Ekonomi \& Pendidikan, 16(2), 69-80.

Boedirachminarni, A., \& Suliswanto, M. S. W. (2017). Analisis kepuasan pengunjung ekowisata Kabupaten Malang. Jurnal Ekonomi Pembangunan, 15(1), 105-116. https://doi.org/10.22219/jep.v15i1.4649

Boo, E. (2008). Ecotourism: The potentials and pitfalls (Digital Ed). World Wildlife Fund.

Bradshaw, M. J. (2004). Effective learning: What teachers need to know. In A. J. Lowenstein \& M. J. Bradshaw (Eds.), Fuszard's Innovative Teaching Strategies in Nursing (pp. 318). Jones \& Bartlett Learning, LLC.

Brown, E. J. (2010). Education in the wild: contextual and location-based mobile learning in action. A report from the STELLAR Alpine Rendez-Vous workshop series. http://tinyurl.com/edwild

Budiyanto, M. A. K. (2006). Tipologi pengembangan potensi ekotourisme di Jawa Timur.

Budiyanto, M. A. K. (2007). Tipologi pemanfatan potensi ekotourisme sebagai sumber belajar pembelajaran efektif di SMA Jawa Timur.

Budiyanto, M. A. K. (2010). Potensi ekotourisme Kota Batu sebagai sumber belajar berdasarkan indikator the International Ecotourism Society dan Mader. Humanity, 6(1), $1-12$.

Butarbutar, R. R., \& Soemarno, S. (2012). Community empowerment efforts in sustainable ecotourism management in North Sulawesi, Indonesia. J-PAL, 3(1), 1-7. https://jpal.ub.ac.id/index.php/jpal/article/viewFile/120/117 
Caulley, D. N. (2007). Conducting research literature reviews: From the internet to paper [Book review]. Qualitative Research Journal, 7(2), 103-104. https://doi.org/10.3316/QRJ0702103

Chaeroni, H. C. (2018). Implementasi standar proses dalam pembelajaran fiqih di Mts SeKecamatan Purbolinggo Kabupaten Lampung Timur [IAIN Metro]. http://repository.metrouniv.ac.id/id/eprint/2578/1/TESIS HARIYATI CAHAYA CHAERONI\%2C NPM. 1605941.pdf

Claiborne, L., Morrell, J., Bandy, J., \& Bruff, D. (2017). Teaching outside the classroom. Center for TEaching, Vanderbilt University. https://cft.vanderbilt.edu/guides-subpages/teaching-outside-the-classroom/

Coe, R., Aloisi, C., Higgins, S., \& Major, L. E. (2014). What makes great teaching? Review of the underpinning research (Issue October). The Sutton Trust. http://www.suttontrust.com/researcharchive/great-teaching/

Cohen, J., Loeb, S., Miller, L. C., \& Wyckoff, J. H. (2019). Policy implementation, principal agency, and strategic action: Improving Teaching effectiveness in New York City middle schools. In Educational Evaluation and Policy Analysis (No. 67; EdPolicyWorks). https://doi.org/10.3102/0162373719893338

Cydis, S. (2015). Authentic instruction and technology literacy. Journal of Learning Design, 8(1), 68-78. https://doi.org/10.5204/jld.v8i1.222

Ermawati, S., \& Taufiq, H. (2017). Penilaian autentik dan relevansinya dengan kualitas hasil pembelajaran (Persepsi dosen dan mahasiswa IKIP PGRI Bojonegoro). Jurnal Pendidikan Ilmu Sosial, 27(1), 92-103.

Eysenck, M. W., \& Eysenck, M. W. (2018). Effective learning. Simply Psychology, January 2002, 379-395. https://doi.org/10.4324/9781315517933-29

Faraitody, A., \& Ramadhan, F. (2015). Siswa Yang Mengikuti Kegiatan Ekstrakurikuler Bola Basket Sekolah Menengah Atas Negeri 10 Tangerang Tahun 2015.

Farida, S. I., \& Anjani, S. R. (2019). Menumbuhkan jiwa kepemimpinan pada mahasiswa di lingkungan Universitas Pamulang. Inovasi: Jurnal Ilmiah Ilmu Manajemen, 6(2), 1-20. https://doi.org/10.32493/inovasi.v6i2.y2019.p19-20

Fauziyah, N. (2018). Pengembangan kepemimpinan siswa melalui outbound training di SMPN 3 Krian Sidoarjo. FTK UIN Sunan Ampel Surabaya.

Fazey, I., Fazey, J. A., \& Fazey, D. M. A. (2005). Learning more effectively from experience. Ecology and Society, 10(2). https://doi.org/10.5751/ES-01384-100204

Fink, A. (2014). Conducting research literature reviews: From the internet to paper. SAGE Publications Inc. https://libguides.usc.edu/writingguide/literaturereview

Gabdrakhmanov, N. K., Rubtzov, V. A., Baybakov, E. E., Somaeh, H. S., \& Shamil'evich Nugaev, F. (2016). Tourism and sustainable development. In Academy of Strategic Management Journal (Vol. 15, Issue SpecialIssue1, pp. 21-26). https://doi.org/10.1016/b978-0-7506-7789-9.50016-9

Girvan, C., Conneely, C., \& Tangney, B. (2016). Extending experiential learning in teacher professional development. Teaching and Teacher Education, 58, 129-139. https://doi.org/10.1016/j.tate.2016.04.009

Gleason, B. L., Peeters, M. J., Resman-Targoff, B. H., Karr, S., McBane, S., Kelley, K., Thomas, T., \& Denetclaw, T. H. (2011). An active-learning strategies primer for achieving ability-based educational outcomes. American Journal of Pharmaceutical Education, 75(9), 186 (1-12). https://doi.org/10.5688/ajpe759186

Gull, F., \& Shehzad, S. (2015). Effects of cooperative learning on students' academic achievement. Journal of Education and Learning (EduLearn), 9(3), 246. https://doi.org/10.11591/edulearn.v9i3.2071

Hewitt, D. (2008). Understanding effective learning. British Journal of Educational Technology, October, 191.

Hsiung, C. (2012). The effectiveness of cooperative learning. Journal of Engineering 
Education, 101(1). https://doi.org/10.1002/j.2168-9830.2012.tb00044.x

Husamah, H., \& Hudha, A. M. (2018). Evaluation of the implementation of communitybased ecotourism principles in management of Clungup Mangrove Conservation, Sumbermanjing Wetan, Malang. Jurnal Pengelolaan Sumberdaya Alam Dan Lingkungan, 8(1), 86-95. https://doi.org/10.29244/jps1.8.1.86-95

Husamah, H., \& Rahardjanto, A. (2018). OIDDE-PjBL learning model: Problem-solving skillsand product creativity for study of biology prospective teachers. The $3 \mathrm{rd}$ Progressive and Fun Education International Seminar ISBN: , 41-51.

Idris, N. S. (2007). Evaluasi dalam pembelajaran bahasa dan sastra Indonesia di SMA.

Julismin, J. (2009). Alam, sumber belajar yang tidak pernah habis. Jurnal Geografi, 1(1), 7783.

Kiper, T. (2013). Role of ecotourism in sustainable development. In M. Ozyavuz (Ed.), Advances in Landscape Architecture (pp. 773-804). Intech Open. https://doi.org/10.5772/55749

Lotulung, C. F., Ibrahim, N., \& Tumurang, H. (2018). Effectiveness of learning method contextual teaching learning (CTL) for increasing learning outcomes of entrepreneurship education. Turkish Online Journal of Educational Technology TOJET, 17(3), 37-46.

Maharani, A. D., \& Aima, Z. (2014). Pengembangan instrumen penilaian psikomotor pada materi sistem pencernaan kelas XI SMA. Jurnal Pelangi, 6(2), 132-141. https://doi.org/10.22202/jp.2014.v6i2.298

Maryani, E. (2020). Ekowisata: Sarana pendidikan untuk memupuk rasa persatuan, kesatuan dan cinta tanah air. Universitas Pendidikan Indonesia. http://file.upi.edu/Direktori/FPIPS/JUR._PEND._GEOGRAFI/196001211985032ENOK_MARYANI/EKOWISATA-ENOK_MARYANI.pdf

Maulana, M. F. (2015). Implementasi model experiential learning dalam pembelajaran IPA materi energi dan perubahannya siswa kelas IV MI Miftahus Shibyan Mijen Semarang. Fakultas Ilmu Tarbiyah dan Keguruan, Universitas Islam Negeri Walisongo.

Miles, M. B., Huberman, A. C., \& Saldana, J. (2019). Qualitative data analysis. SAGE Publications, Inc. https://us.sagepub.com/en-us/nam/qualitative-dataanalysis/book246128\#contents

Mims, C. (2003). Authentic learning: A practical introduction \& guide for implementation. Meridian, 6(1), 1-3.

Mudzakir, D. O., \& Mubarok, M. Z. (2020). Pengaruh outdoor education terhadap kepercayaan diri siswa dalam ekstrakurikuler. Jurnal Pendidikan Olahraga, 9(1), 1527. https://doi.org/10.31571/jpo.v9i1.1337

Mukhtar, M. (2015). Strategi kepala sekolah dalam meningkatkan kinerja guru pada SMP Negeri di Kecamatan Masjid Raya Kabupaten Aceh Besar. Jurnal Magister Administrasi Pendidikan, 3(3), 103-117.

Mulyadin, M. (2017). Strategi guru dalam pembentukan karakter keberanian dan kemandirian siswa melalui pembelajaran tematik di Madrasah Ibtidaiyah desa Pesa kecamantan Wawo kabupaten Bima. UIN MMI Malang.

OECD. (2009). Creating effective teaching and learning environments: First results from TALIS (Executive Summary).

Parera, R. M. (2005). Hakekat proses belajar. Grasindo.

Pedaste, M., Mäeots, M., Siiman, L. A., de Jong, T., van Riesen, S. A. N., Kamp, E. T., Manoli, C. C., Zacharia, Z. C., \& Tsourlidaki, E. (2015). Phases of inquiry-based learning: Definitions and the inquiry cycle. Educational Research Review, 14, 47-61. https://doi.org/10.1016/j.edurev.2015.02.003

Podschuweit, S., \& Bernholt, S. (2018). Composition-effects of context-based learning opportunities on students' understanding of energy. Research in Science Education, 48(4), 717-752. https://doi.org/10.1007/s11165-016-9585-z 
Poerwanti, E. (2015). Konsep dasar asesmen pembelajaran. In Asesmen Pembelajaran di SD (Issue 1, pp. 1-44). Kemendikbud.

Prameswari, S. J., \& Budiyanto, C. (2017). The development of the effective learning environment by creating an effective teaching in the classroom. IJIE (Indonesian Journal of Informatics Education), 1(1), 79-86. https://doi.org/10.20961/ijie.v1i1.11960

Qodir, A. (2017). Evaluasi dan penilaian pembelajaran. K-Media.

Rahardjanto, A., Husamah, H., \& Fauzi, A. (2019). Hybrid-PjBL: Learning outcomes, creative thinking skills, and learning motivation of preservice teacher. International Journal of Instruction, 12(2), 179-192. https://doi.org/10.29333/iji.2019.12212a

Ratnawulan, E., \& Rusdiana, A. (2014). Evaluasi pembelajaran: Dengan pendekatan kurikulum 2013. Pustaka Setia.

Rusita, R., Walimbo, R., Sari, Y., \& Yanti, M. (2016). Studi potensi objek dan daya tarik wisata alam air terjun wiyono di Taman Hutan Raya Wan Abdul Rahman, Provinsi Lampung. Info Teknik, 17(2), 165-186.

Saepuddin, A. (2016). Merancang teknik penilaian berbasis kelas: Kasus guru fiqih tsanawiyah. Jurnal Pendidikan Islam, 27(1), 47-65. https://doi.org/10.15575/jpi.v27i1.495

Schunk, D. H. (2012). Learning theories: An educational perspective. In Reading (Vol. 5). Pearson. http://www.amazon.com/Learning-Theories-Educational-Perspective6th/dp/0137071957

Schwartz, M. (2012). Best Practices in Experiential Learning (McGill/Ryerson). In Best Practices in Experiental Learning.

Setiyanti, S. W. (2012). Membangun kerja sama tim (kelompok). JURNAL STIE SEMARANG, 4(3), 59-65.

Silva, A. B. Da, Bispo, A. C. K. de A., Rodriguez, D. G., \& Vasquez, F. I. F. (2018). Problem-based learning: A proposal for structuring PBL and its implications for learning among students in an undergraduate management degree program. Revista de Gestão, 25(2), 160-177. https://doi.org/10.1108/REGE-03-2018-030

Singh, J., \& Kaushik, V. (2020). The study of the effectiveness of the inquiry- based learning method in chemistry teaching learning process. Adalya Journal, 9(4), 234-237. https://doi.org/10.37896/aj9.4/058

Smith, R., \& Betts, M. (2000). Learning as partners: Realising the potential of work-based learning. Journal of Vocational Education and Training, 52(4), 589-604. https://doi.org/10.1080/13636820000200147

Stevens, B. B. (Ed.). (2014). Career and technical education work-based learning guide. Virginia Department of Education. https://doi.org/10.4324/9781315268071-8

Sunani, N. H. (2010). Sistem penilaian berbasis kelas dalam pembelajaran Bahasa Indonesia (Studi kebijakan di SMP Negeri Kabupaten Karanganyar).

Suryaningsih, Y. (2018). Ekowisata sebagai sumber belajar biologi dan strategi untuk meningkatkan kepedulian siswa terhadap lingkungan. Bio Educatio, 3(2), 59-72.

TIES. (2016). What is ecotourism? The International Ecotourism Society. https://ecotourism.org/what-is-ecotourism/\%0Ahttps://ecotourism.org/what-isecotourism/\%0Ahttps://www.ecotourism.org/what-is-ecotourism

Tim Direktorat Pembinaan SMP. (2017). Panduan penilaian oleh pendidik dan satuan pendidikan sekolah menengah atas. Kementerian Pendidikan dan Kebudayaan.

Watkins, C., Carnell, E., Lodge, C., Wagner, P., \& Whalley, C. (2005). Learning about learning: Resources for supporting effective learning. Routledge-Falmer. https://doi.org/10.4324/9780203991886

White, M. D., \& Marsh, E. E. (2006). Content analysis: A flexible methodology. Library Trends, 55(1), 22-45. https://doi.org/10.1353/lib.2006.0053

Widyaningtyas, D., \& Farid, M. (2015). Pengaruh experiential learning terhadap kepercayaan 
diri dan kerjasama tim remaja. Persona: Jurnal Psikologi Indonesia, 3(3), 237-246. https://doi.org/10.30996/persona.v3i03.413

Wijayanti, A. (2014). Pengembangan autentic assesment berbasis proyek dengan pendekatan saintifik untuk meningkatkan keterampilan berpikir ilmiah mahasiswa. Jurnal Pendidikan IPA Indonesia, 3(2), 102-108.

Winaryati, E. (2018). Penilaian kompetensi siswa abad 21. Prosiding Seminar Nasional \& Internasional, 1(1), 6-19.

Wulandari, Z., Mintarti, S. U., \& Haryono, A. (2020). Pendidikan ekowisata pada masyarakat sekitar wisata Sumber Maron Desa Karangsuko. Jurnal Ekonomi Pendidikan Dan Kewirausahaan, 8(2), 151-164. https://doi.org/10.26740/jepk.v8n2.p151-164

Yew, E. H. J., \& Goh, K. (2016). Problem-based learning: An overview of its process and impact on learning. Health Professions Education, 2(2), 75-79. https://doi.org/10.1016/j.hpe.2016.01.004

Yudha, R. P., Masrukan, M., \& Djuniadi, D. (2014). Pengembangan instrumen asesmen otentik unjuk kerja materi bangun ruang di sekolah dasar. Journal of Educational Research and Evaluation, 3(2), 62-67.

Zwane, S. L., \& Malale, M. M. (2018). Investigating barriers teachers face in the implementation of inclusive education in high schools in Gege branch, Swaziland. African Journal of Disability, 7, 1-12. https://doi.org/10.4102/ajod.v7i0.391 